\title{
Contribution of changes in opal productivity and nutrient distribution in the coastal upwelling systems to Late Pliocene/Early Pleistocene climate cooling
}

\author{
J. Etourneau ${ }^{1,2}$, C. Ehlert ${ }^{3}$, M. Frank ${ }^{3}$, P. Martinez ${ }^{4}$, and R. Schneider ${ }^{1}$ \\ ${ }^{1}$ Institut für Geowissenschaften, Universität zu Kiel, Ludewig-Meyn-Str. 10, 24118 Kiel, Germany \\ ${ }^{2}$ LOCEAN, CNRS/UPMC/IRD/MNHN - UMR7159, 4 Place Jussieu, 75252 Paris, France \\ ${ }^{3}$ GEOMAR, Helmholtz Centre for Ocean Research Kiel, Wischhofstrasse 1-3, 24118 Kiel, Germany \\ ${ }^{4}$ Université Bordeaux 1, EPOC - UMR5805, Avenue de Facultés, 33405 Talence, France \\ Correspondence to: J. Etourneau (johan.etourneau@ locean-ipsl.upmc.fr)
}

Received: 23 February 2012 - Published in Clim. Past Discuss.: 6 March 2012

Revised: 13 August 2012 - Accepted: 20 August 2012 - Published: 13 September 2012

\begin{abstract}
The global Late Pliocene/Early Pleistocene cooling $(\sim 3.0-2.0$ million years ago $-\mathrm{Ma})$ concurred with extremely high diatom and biogenic opal production in most of the major coastal upwelling regions. This phenomenon was particularly pronounced in the Benguela upwelling system (BUS), off Namibia, where it is known as the Matuyama Diatom Maximum (MDM). Our study focuses on a new diatom silicon isotope $\left(\delta^{30} \mathrm{Si}\right)$ record covering the MDM in the BUS. Unexpectedly, the variations in $\delta^{30} \mathrm{Si}$ signal follow biogenic opal content, whereby the highest $\delta^{30} \mathrm{Si}$ values correspond to the highest biogenic opal content. We interpret the higher $\delta^{30} \mathrm{Si}$ values during the MDM as a result of a stronger degree of silicate utilisation in the surface waters caused by high productivity of mat-forming diatom species. This was most likely promoted by weak upwelling intensity dominating the BUS during the Late Pliocene/Early Pleistocene cooling combined with a large silicate supply derived from a strong Southern Ocean nutrient leakage responding to the expansion of Antarctic ice cover and the resulting stratification of the polar ocean 3.0-2.7 Ma ago. A similar scenario is hypothesized for other major coastal upwelling systems (e.g. off California) during this time interval, suggesting that the efficiency of the biological carbon pump was probably sufficiently enhanced in these regions during the MDM to have significantly increased the transport of atmospheric $\mathrm{CO}_{2}$ to the deep ocean. In addition, the coeval extension of the area of surface water stratification in both the Southern Ocean and the North Pacific, which decreased
\end{abstract}

$\mathrm{CO}_{2}$ release to the atmosphere, led to further enhanced atmospheric $\mathrm{CO}_{2}$ drawn-down and thus contributed significantly to Late Pliocene/Early Pleistocene cooling.

\section{Introduction}

The causes and consequences of global Late Pliocene/Early Pleistocene cooling (ca. 3.0-2.0 Ma) have been subject to numerous investigations in order to understand mechanisms driving global climate from a state warmer than today towards colder conditions (Lisiecki and Raymo, 2005). Recent studies attributed this major climatic transition to a pronounced atmospheric $\mathrm{CO}_{2}$ decline of about $\sim 100 \mathrm{ppm}$, from 400-350 to 300-250 ppm (Bartoli et al., 2011; Pagani et al., 2010; Tripati et al., 2010; Seki et al., 2010), which would have promoted a significant extension of the polar ice caps and the onset of significant glaciation in the Northern Hemisphere (Lunt et al., 2008). However, the processes driving this atmospheric $\mathrm{CO}_{2}$ drawn-down are not completely understood. Closely related phenomena in this context are global changes of the efficiency of the biological carbon pump and biogeochemical cycles in both high and low latitude oceanic regions tied to the reorganization of the nutrient distribution and interactions between the different ocean basins.

Over the past $5.0 \mathrm{Ma}$, the most outstanding example of long-term and global productivity changes coinciding with oceanic and atmospheric circulation changes were recorded 
during the Late Pliocene/Early Pleistocene cooling. A pronounced shift of the centres of opal deposition linked to diatom productivity from the North Pacific and Southern Ocean to the regions of the low-latitude eastern boundary currents occurred between 3.0 and 2.4 Ma followed by a second shift from the coastal upwelling regions to the Southern Atlantic Ocean between 2.4 and $2.0 \mathrm{Ma}$ (Cortese et al., 2004), where they are largest in the modern ocean. In the BUS, this extremely high siliceous productivity event, the socalled MDM (Berger et al., 2002; Lange et al., 1999; Pérez et al., 2001), is represented by sedimentary biogenic opal concentrations of up to $60 \%$ along the continental slopes off Namibia and southwest Africa between the Walvis Ridge and Cape Town (Wefer et al., 1998). This high biogenic opal abundance coincided with the first appearance of the diatom flora (e.g. Thalassiothrix antarctica) presently prevailing in the Southern Ocean (Berger et al., 2002; Lange et al., 1999; Pérez et al., 2001), which paradoxically evolved under warm surface water conditions and weak upwelling intensity (Etourneau et al., 2009).

The reasons for these changes are particularly intriguing because similar and synchronous maxima in biogenic opal production have also been reported in other coastal upwelling systems, such as off California and Mauritania (Janecek, 2000; Tiedemann, 1991), at which a similarly dramatic SST decline of about $3-4{ }^{\circ} \mathrm{C}$ was recorded in all these three areas (Dekens et al., 2007; Etourneau et al., 2009; Herbert and Schuffert, 1998; Liu et al., 2008; Marlow et al., 2000). The most pressing questions regarding the cause of the MDM are therefore: (i) how to explain the co-occurrence of the largest amount of Antarctic diatom mats concomitant with surface water conditions in the coastal upwelling regions characterized by high temperatures and stratification most of the year during the Late Pliocene/Early Pleistocene?(ii) Why did the decline of the Antarctic diatom flora accompany the decrease in opal production when upwelling intensified at the beginning of the early Pleistocene, despite the fact that the development of the upwelling system should have enhanced nutrient supply and sustained higher diatom productivity? (iii) Given the importance of the changes in global opal productivity for the carbon cycle, to what extent did these major shifts of the centres of opal production promote Late Pliocene/Early Pleistocene climate cooling?

To answer these fundamental questions, we first investigate the causes of the onset and the end of the MDM in the BUS, one of the major areas where this high biogenic opal production was most pronounced. Using a comparison of proxies, we reconstruct regional biogeochemical cycling between 3.0 and $1.5 \mathrm{Ma}$ in the BUS. We then compared our results from this region to other upwelling systems and regarding related changes in the polar oceans during this time interval we propose a scenario illustrating a possible significant impact of the MDM on the Plio-Pleistocene global climate transition.

\section{Material and methods}

\section{$2.1 \quad$ IODP Site 1082}

To conduct this study, we generated a new $\delta^{30} \mathrm{Si}$ record of diatom opal for the well-dated Benguela ODP (Ocean Drilling Program) Site 1082 , Hole A ( $21^{\circ} 06^{\prime} \mathrm{S}, 11^{\circ} 49^{\prime} \mathrm{E}, 1279 \mathrm{~m}$ water depth) located on the Walvis Ridge in the northern Cape basin, which is compared with nitrogen isotopes $\left(\delta^{15} \mathrm{~N}\right)$ and biogenic opal content $(\mathrm{BSi})$ and mass accumulation rates (MAR). Stratigraphy of Site 1082 has previously been described extensively by Etourneau et al. (2009). In the centre of the BUS, at Site 1084 (Fig. 1), the upwelling presently is active year-round, while in the north, where the IODP Site 1082 is located, the upwelling cells develop only seasonally (Shannon, 1985) making the study site at a suitable location for recording past changes in upwelling intensity. Silicic acid $\left(\mathrm{Si}(\mathrm{OH})_{4}\right)$ and nitrate $\left(\mathrm{NO}_{3}^{-}\right)$are today mainly supplied from the Southern Ocean (Fig. 1) through the resurgence of Antarctic Intermediate Water (AAIW) and subantarctic mode waters (SAMW) that form in the polar frontal system zone of the Atlantic Sector of the Southern Ocean (Shannon, 1985). When the wind-driven coastal upwelling off Namibia intensifies, nutrients are carried to the surface and support high productivity levels.

\subsection{Silicon isotope compositions $\left(\delta^{30} \mathrm{Si}\right)$ of diatoms}

The downcore $\delta^{30} \mathrm{Si}$ record was obtained from diatom biogenic opal. The extraction of diatoms from the sediment followed the procedure of Morley et al. (2004). In the fraction 11-23 $\mu \mathrm{m}$, diatoms are by far the most abundant opaline organisms. After each extraction and purification step, the diatom opal samples were visually controlled under the microscope, and were then, according to the result, treated again with heavy liquid separation (at a slightly different density than before) or were wet-sieved again to purify this size-fraction as much as possible. By applying the separation steps carefully, the "contaminations" originating from other siliceous organisms (e.g. radiolarians) could be reduced to a very small amount (below approximately $5 \%$ ), so that a significant influence on the $\mathrm{Si}$ isotope data is highly unlikely.

The diatom opal was then dissolved in $1 \mathrm{ml} 0.1 \mathrm{~N} \mathrm{NaOH}$ at $130^{\circ} \mathrm{C}$ for several hours (usually overnight), and then centrifuged. The supernatant solution was thereafter transferred into new teflon vials. $200 \mu \mathrm{l}$ of $\mathrm{H}_{2} \mathrm{O}_{2}$ were added to remove any remaining organic matter. After most of the reaction had ended, the samples were dried down and re-dissolved in $1 \mathrm{ml}$ $0.1 \mathrm{~N} \mathrm{NaOH}$ at $130^{\circ} \mathrm{C}$ overnight. The still warm resulting samples were then diluted with $4 \mathrm{~mL}$ MQ water, and were neutralised with $0.1 \mathrm{ml} 1 \mathrm{~N} \mathrm{HCl}$. Sample aliquots were used to determine Si concentrations using a colorimetric method on a photospectrometer (Hansen and Koroleff, 1999). The chromatographic separation and purification (De Souza et al., 2012; Georg et al., 2006; Reynolds et al., 2008) was achieved 

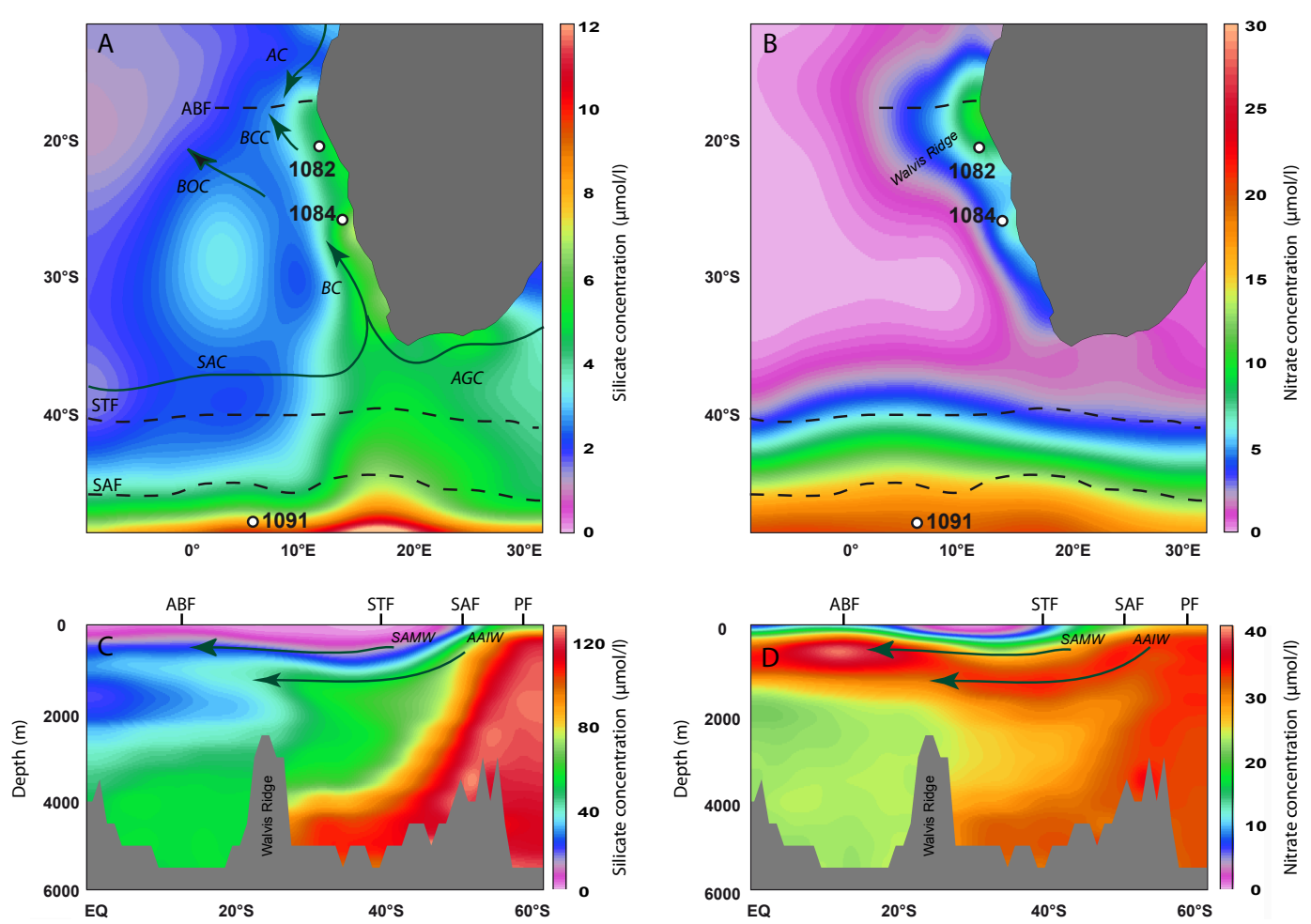

Fig. 1. Silicate and nitrate concentrations $\left(\mu \mathrm{mol} 1^{-1}\right)$ at $10 \mathrm{~m}$ water depth $(\mathbf{A}, \mathbf{B})$ and of water masses along a latitudinal transect $(\mathbf{C}, \mathbf{D})$. White dots indicate the location of the Benguela ODP Sites 1082 and 1084 as well as the South Atlantic Site 1091. As illustrated here, Si is supplied in the BUS by the upwelling of SAMW, subantarctic mode waters, and AAIW, Antarctic Intermediate Waters, formed in the Southern Ocean, in the polar frontal system zone. AC, Angola Current; AGC, Aghulas Current; BC, Benguela Current; BCC, Benguela Coastal Current; BOC, Benguela Oceanic Current; SAC, South Atlantic Current; STF, Subtropical Front; SAF, Subantarctic Front.

with a precleaned $1 \mathrm{ml}$ BioRad ion exchange column filled with AG50W-X8 (200-400 mesh) cation exchange resin.

All $\delta^{30} \mathrm{Si}$ ratios were measured on a Nu instruments MCICPMS at GEOMAR in Kiel, which is equipped with an adjustable entrance slit for medium resolution to ensure peak separation of the ${ }^{30} \mathrm{Si}$ peak and the molecular interference of ${ }^{14} \mathrm{~N}^{16} \mathrm{O}$. The sample and standard solutions were introduced into the plasma via a Cetac Aridus II desolvator equipped with a PFA nebulizer at a 60 to $80 \mu \mathrm{min}^{-1}$ uptake rate. Measurements were achieved with a standard-sample-standard bracketing method (Albarède et al., 2004). Samples and standards were measured with a concentration of 0.4 to $0.6 \mathrm{ppm}$ depending on the performance of the instrument on the measurement day. All silicon isotope results in this study are presented in the $\delta^{30} \mathrm{Si}$ notation as follows:

$\delta^{30} \mathrm{Si}=\left(\left({ }^{30} \mathrm{Si} /{ }^{28} \mathrm{Si}_{\text {sample }} /{ }^{30} \mathrm{Si} /{ }^{28} \mathrm{Si}_{\text {standard }}\right)-1\right) \cdot 1000$

representing deviations of the measured ${ }^{30} \mathrm{Si} /{ }^{28} \mathrm{Si}$ from the international Si standard NBS28 in parts per thousand (\%o).

Measurements of the inter-laboratory standards IRMM018 and Big Batch gave average values of $\delta^{30} \mathrm{Si}=-1.62 \pm 0.26 \% \circ(2 \sigma)$ and $-10.73 \pm 0.27 \%$ o $(2 \sigma)$, respectively. These values are in good agreement with values obtained by other laboratories (Reynolds et al.,
2007). Samples were measured three to five times within a day session, which resulted in external errors between 0.06 and $0.29 \%$ in $\delta^{30} \mathrm{Si}(2 \sigma)$. Duplicate measurements over a longer period of time $(n=20$ sessions/days within one year) of an in-house matrix standard gave a reproducibility of $\pm 0.25 \%$ in $\delta^{30} \mathrm{Si}(2 \sigma)$.

In order to test if the isotopic ratios are consistent with mass dependent fractionation (mean for kinetic and equilibrium fractionation), as occurs during biological processes, we plotted the $\delta^{30} \mathrm{Si}$ versus the $\delta^{29} \mathrm{Si}$ (Fig. 2). The theoritical mass dependent fractionation between both isotopes is 0.5135 (Reynolds et al., 2006). The calculated fractionation for the data of our study is 0.5006 . Both are, within the uncertainties of stable silicon isotope measurements on a MC-ICPMS, indistinguishable from each other and suggest that any molecular interferences were fully eliminated. 


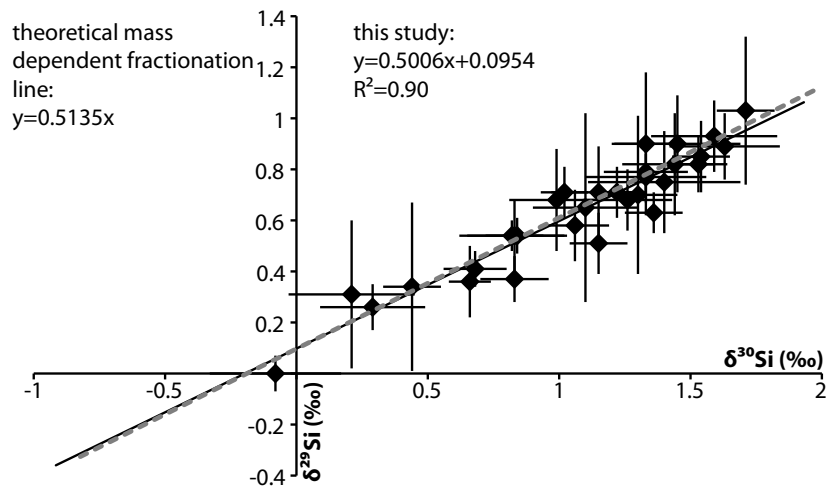

Fig. 2. $\delta^{30} \mathrm{Si}(\%)$ versus $\delta^{29} \mathrm{Si}(\%)$.

\section{Results and discussion}

\subsection{Diatom- $\delta^{30}$ Si evidence for local changes in Si cycling during the MDM}

During the MDM interval, the diatom $\delta^{30} \mathrm{Si}$ values at Site 1082 were in the range expected for an upwelling area but experienced large amplitude changes ranging between $\sim 0$ and $1.7 \%$ (Fig. 3). Except between 3.2 and 3.0 Ma where two high $\delta^{30} \mathrm{Si}$ values concurred with low BSi MAR, the lowest values around $0.3-0.4 \%$ generally coincide with minima in BSi content $(<20 \%)$ and BSi MAR $\left(1 \mathrm{~g} \mathrm{~cm}^{-2} \mathrm{ka}^{-1}\right)$, whereas the highest values (up to 1.4-1.7\%o) correspond to the maxima of opal accumulation rates and diatom productivity (respectively, up to $60 \%$ and $4 \mathrm{~g} \mathrm{~cm}^{-2} \mathrm{ka}^{-1}$ ). Given that diatoms fractionate the dissolved seawater Si by $-1.1 \%$ during incorporation into their opal frustules (De La Rocha et al., 1997), $\delta^{30} \mathrm{Si}$ values of up to $1.7 \%$ o suggest that the surface waters in which the diatoms grew had isotopic values in the order of $2.8 \%$, whereas surface water values of only $1.5 \%$ are reconstructed for minimum diatom signatures of $0.4 \%$. For comparison, the bulk sediment and diatombound $\delta^{15} \mathrm{~N}$ was at a minimum during the MDM and revealed very light values around $0-2 \%$, while after $2.4 \mathrm{Ma}$, the values increased to 4-5\%o during the Mid-Pleistocene (Fig. 3) (Etourneau et al., 2009; Robinson and Meyers, 2002) which is consistent with the distribution found in the modern situation (Pichevin et al., 2005).

Similar to nitrogen isotopes $\left(\delta^{15} \mathrm{~N}\right)$, silicon isotopes $\left(\delta^{30} \mathrm{Si}\right)$ are fractionated during utilisation in the surface waters in a way that the lighter $\mathrm{Si}$ isotopes are preferentially incorporated into diatom frustules (De La Rocha et al., 1998, 2000; Brzezinski et al., 2002; Varela et al., 2004), which leaves the ambient seawater enriched in the heavier isotopes. The degree of depletion thus determines the magnitude of isotopic fractionation and together with water mass mixing controls the dissolved signature in ambient seawater (e.g. Reynolds et al., 2006).

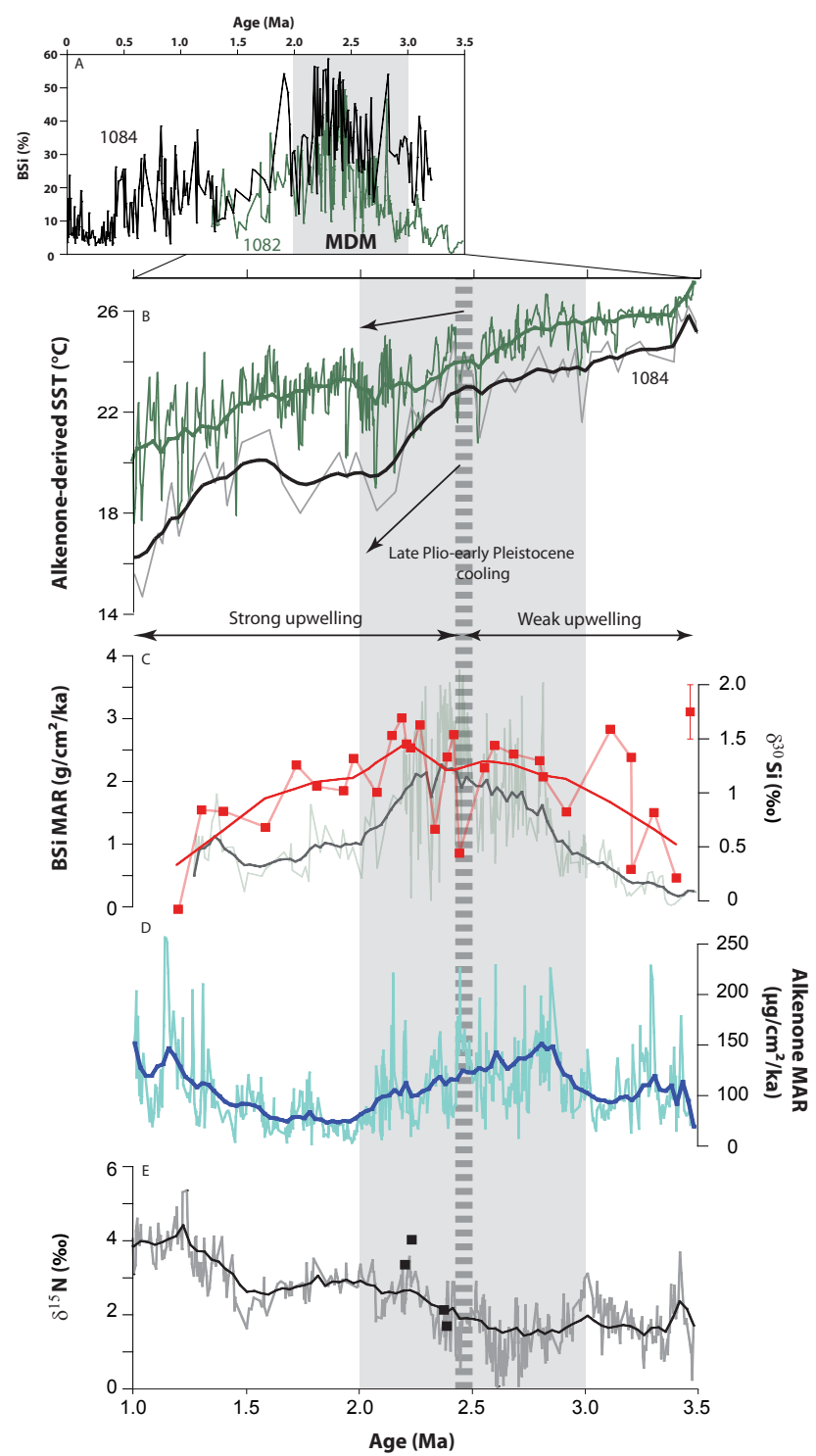

Fig. 3. (A) BSi content (\%) at the Benguela Sites 1082 (green) and 1084 (black) (Etourneau et al., 2009; Lange et al., 1999; Pérez et al., 2001; Robinson and Meyers, 2002). (B) Alkenone-derived SST records at Sites 1082 (green) (Etourneau et al., 2009) and 1084 (black) (Marlow et al., 2000). (C) $\delta^{30} \mathrm{Si}$ (\%o) (red) (this study) and BSi mass accumulation rate (MAR) $\left(\mathrm{g} \mathrm{cm}^{-2} \mathrm{ka}^{-1}\right)$ (light green) (Etourneau et al., 2009). (D) Alkenone MAR record (blue) (Etourneau et al., 2009). (E) Bulk $\delta^{15} \mathrm{~N}$ (black) (Etourneau et al., 2009) and diatom-bound $\delta^{15} \mathrm{~N}$ (black squares) (Robinson and Meyers, 2002) records at Site 1082. The solid lines for each records corresponds to the smoothed curve. Age models of Sites 1082 and 1084 are described in Etourneau et al. (2009). In panel (B), the longterm reproducibility of the $\delta^{30} \mathrm{Si}$ measurements is indicated by the error bar. 
In this study, on the basis of our current knowledge, we assume that the $\delta^{30} \mathrm{Si}$ signature of the water masses during the MDM was similar to nowadays (De La Rocha and Bickle, 2005). We also consider the effects of differences in Si isotope fractionation between diatom species and their respective ecological niches negligible. As previously documented, the composition of diatom species changed at $\sim 3.0 \mathrm{Ma}$, from mixed diatom assemblages to a dominance of $T$. antarctica, a mat-forming diatom species characterizing the MDM, replaced again thereafter at $\sim 2.4-2.0 \mathrm{Ma}$ by dominating Chaetoceros spores and cetae (Berger et al., 2002; Lange et al., 1999; Pérez et al., 2001). Changes in diatom assemblages may therefore potentially have affected the isotopic signal at IODP Site 1082. However, no drastic fluctuations in the $\delta^{30} \mathrm{Si}$ - and $\delta^{15} \mathrm{~N}$ - values accompanied these faunistic changes (Fig. 3). Instead, the $\delta^{30} \mathrm{Si}$ record followed the BSi MAR variations since $3.0 \mathrm{Ma}$ which implies that the $\delta^{30} \mathrm{Si}$ signature was unlikely affected by changes in diatom assemblages but rather reflects past nutrient utilisation and supply conditions. This assumption is supported by findings of De La Rocha et al. (1997) who reported results from culture experiments showing that three different diatom species had strictly the same fractionation factor. There is, therefore, no proven evidence that a change in diatom assemblage impacts the $\delta^{30} \mathrm{Si}$ values reconstructed in the BUS during the MDM.

In addition, Chaetoceros is a diatom species living in the surface waters, whereas $T$. antarctica can migrate through the water column to feed in the nutricline and realise photosynthesis at the surface. Few studies focused on the effects of differences in depth, in which the diatoms grew and the possible differences of the isotopic signature of seawater on the $\delta^{30} \mathrm{Si}$ values of the diatoms. Cardinal et al. (2007) and Fripiat et al. (2011) demonstrated that in the Southern Ocean, the $\delta^{30} \mathrm{Si}$ values of the diatoms living in the mixed layer were nearly the same as those measured on diatoms growing in deeper layers. Some variations were found but remained overall low and are much smaller than those reconstructed by our $\delta^{30} \mathrm{Si}$ record. We therefore conclude that the effects of different diatom assemblages and their respective environment of growth are not significant enough to influence the $\delta^{30} \mathrm{Si}$ variations.

Dissolution of diatom frustules during the downward transport in the water column to the sediment may also affect the isotopic signature of Si. According to Demarest et al. (2009), if the preservation efficiency between different diatom assemblages has a difference $>20 \%$ from each other, then the $\delta^{30} \mathrm{Si}$ might change by $\pm 0.1 \%$, whereby this process increases linearly as dissolution progresses. As previously demonstrated, Chaetoceros shows a high resistance to dissolution (Koning et al., 2001), and T. antarctica builds mats which usually are also well protected against dissolution (Ragueneau et al., 2000). This feature explains why well-preserved diatoms are found in the BUS sediment during the Plio-Pleistocene climate transition (Lange et al., 1999). We are therefore confident that the $\delta^{30} \mathrm{Si}$ measured on the biogenic opal is not significantly influenced by dissolution and its effect is most likely minor regarding the large amplitude variations in our $\delta^{30} \mathrm{Si}$ record.

Today, the BUS is mainly supplied with Si from the Southern Ocean waters through equatorward advection and upwelling of SAMW and AAIW (Fig. 1). During the MDM, the polar frontal system regions where these water masses are presently formed may have been poorly developed prior to $2.1 \mathrm{Ma}$ (Liu et al., 2008). We therefore suspect that the two water masses might have originated either further south or from a wider area during the MDM. The extension of the Antarctic ice cap and the progressive stratification of the "warm" Southern Ocean at $\sim 3.0-2.7 \mathrm{Ma}$ (Haug et al., 1999; Martinez-Garcia et al., 2010) likely favoured the delivery of Si to the BUS through SAMW and AAIW, and unlikely from surface water advection. Indeed, the lack of coherency between the $\delta^{15} \mathrm{~N}$ values from the BUS and the polar frontal region do not support surface water advection as a possible source of nutrients along the southwestern African coast (Etourneau et al., 2009). The hydrological changes in the Southern Ocean most likely allowed the transfer of a large amount of unused $\mathrm{Si}$ in the Southern Ocean to the lowlatitude upwelling systems (Cortese et al., 2004; Hillenbrand and Cortese, 2006). The presence of diatom species typical for Southern Ocean waters in the BUS (Berger et al., 2002; Lange et al., 1999; Pérez et al., 2001) confirms the close connection between the two regions during the MDM. According to sedimentary archives, productivity during the MDM was mostly dominated by carbonate producers in the polar frontal (PF) region of the Southern Ocean (e.g. ODP Site 1090; Gersonde et al., 1999). In addition, very few diatoms or other opal producers were found south of the PF at that time (e.g. ODP Sites 1095, Hillenbrand and Cortese, 2006; and 1096, Hillenbrand and Fütterer, 2001), which supports the conclusion that the original silica pool feeding the BUS was poorly utilised. This observation therefore minimises potential effects of diatom dissolution in the Southern Ocean water column potentially affecting the $\delta^{30} \mathrm{Si}$ values advected waters to the BUS because this process, as previously observed in culture experiments (Demarest et al., 2009), should have led to low $\delta^{30} \mathrm{Si}$ signatures in the BUS and not the high ones observed.

Moreover, supposing a similar reorganization of the nutrient cycles between the North Pacific and the Southern Ocean during the extension of the polar ice cover and the stratification of the polar oceans $\sim 3.0-2.7 \mathrm{Ma}$, the decline in biogenic opal producers in both regions may have been accompanied by a reduced silicate utilisation in the Southern Ocean and thereby have led to lower $\delta^{30} \mathrm{Si}$ values comparable to those reconstructed in the North Pacific (from $\sim 1.6$ to $\sim 1.2 \%$ around $\sim 2.73 \mathrm{Ma}$ ) (Reynolds et al., 2008). This implies that the isotopic signature of waters entering the BUS was most likely low or at least much lower than the values calculated for the surface waters in the BUS for the subsequent period between 3.0 and 2.0 Ma. We therefore argue that 
the extracted isotopic signal of the diatoms in the Benguela upwelling system most likely reflects a local signature and recorded the utilisation of Si by locally produced diatoms rather than changes in the advected dissolved $\delta^{30} \mathrm{Si}$ signature.

\subsection{Evidence for a weak BUS during the MDM}

According to our results, a relatively high degree of silicic acid utilisation should correspond to heavy diatom $\delta^{30} \mathrm{Si}$ values, i.e. close to $1.8 \%$, and vice versa. Consequently, the MDM was characterized by a high rate silicate utilisation by locally-produced diatoms, mostly $T$. antarctica mats. However, these high isotopic values occurred during the interval of highest BSi concentrations. In addition, the highest BSi values also appeared during a period where the nitrate was largely unutilised as illustrated by the low $\delta^{15} \mathrm{~N}$ values (Fig. 3) (Etourneau et al., 2009). Although the bulk $\delta^{15} \mathrm{~N}$ values recorded an isotopic signature derived from a mixture of organic matter, its good coherency with the diatom-bound $\delta^{15} \mathrm{~N}$ values determined at the same site (Robinson and Meyers, 2002) demonstrates that the sedimentary $\delta^{15} \mathrm{~N}$ signatures mostly reflected changes in surface water conditions and nitrate uptake by locally produced diatom species. Taken together, the high BSi MAR and $\delta^{15} \mathrm{~N}$ records would therefore suggest a strong upwelling of nutrient-rich subsurface waters. The MDM in the BUS thus should also have corresponded to a lower and not a higher degree of silicate utilisation because of the silica-rich subsurface waters supply, whereas the opposite is observed.

An anticorrelation between the $\delta^{15} \mathrm{~N}$ and $\delta^{30} \mathrm{Si}$ records has also been described in the North Pacific (Reynolds et al., 2008) during the onset of significant Northern Hemisphere glaciation and the associated establishment of stratification of the surface waters at $2.73 \mathrm{Ma}$. A similar pattern has been found in the Southern Ocean during the last glacialinterglacial cycles (De La Rocha et al., 1998; Brzezinski et al., 2002). In the latter study, the authors ascribed the high $\delta^{15} \mathrm{~N}$ and the low $\delta^{30} \mathrm{Si}$ and BSi during the last glacial periods to enhanced iron $(\mathrm{Fe})$ fertilisation that would have generated preferential utilisation and uptake of $\mathrm{N}$ by diatoms instead of $\mathrm{Si}$ and therefore, to a higher degree of $\mathrm{N}$ fractionation compared with Si isotopes (Brzezinski et al., 2002). Comparatively, in the North Pacific, the $\delta^{15} \mathrm{~N}$ increased with the stratification of the surface waters at 2.73 Ma, while the $\delta^{30} \mathrm{Si}$ and BSi MARs declined. Reynolds et al. (2008) argued that the inverse relationship between the proxies could not have been caused by an increase in $\mathrm{Fe}$ fertilisation as the opal productivity decreased instead of increased. They rather ascribed the anticorrelation to the combined sea ice and surface water stratification effects that limited the light and largely inhibited the upwelling of nutrients, thus causing a more complete $\mathrm{N}$ utilisation in this region compared with that of $\mathrm{Si}$.

Contrary to the North Pacific or the Southern Ocean, the BUS has been located along the coast and is supplied with large amounts of $\mathrm{Fe}$ through aeolian dust. It is therefore unlikely that $\mathrm{Fe}$ has played a major role for the observed $\delta^{15} \mathrm{~N}, \delta^{30} \mathrm{Si}$, and $\mathrm{BSi}$ variations, despite possible changes in Fe supply tied to varying hinterland climate conditions (Dupont, 2006). In upwelling areas, such as the Benguela system, for which currently no water column or sedimentary diatom $\mathrm{Si}$ isotope data exist, it is expected that during periods of most intense upwelling activity the continuous supply of relatively unfractionated $\mathrm{Si}$ with low $\delta^{30} \mathrm{Si}$ leads to a strong or complete utilisation signature of the $\mathrm{Si}$, owing to the presence of other limiting nutrients (e.g. phosphorus), and thus does not lead to strongly fractionated $\mathrm{Si}$ in the diatoms (at least not as high as $1.8 \%$ ). In contrast, when upwelling is weaker, most of the $\mathrm{Si}$ in the surface waters should be utilised and the corresponding $\mathrm{Si}$ isotope values recorded by the diatoms is high as observed in the subtropical gyre of the North Pacific (Reynolds et al., 2012). This is probably the case for the period between 3.2 and 3.0 Ma during which the system behaved as "expected" with a high utilisation of $\mathrm{Si}$ (high $\delta^{30} \mathrm{Si}$ values) accompanied by a low opal productivity and at the same time a low utilisation of nitrate (low $\delta^{15} \mathrm{~N}$ values) within a warm BUS. During this time interval, the local primary productivity was probably limited by silicic acid availability owing to a weak upwelling activity.

Compared to the high silicate utilisation, the supply of nitrate in the BUS between 3.0 and $2.4 \mathrm{Ma}$ was probably surpassing the nitrate demand of primary producers in the BUS (Etourneau et al., 2009), as suggested by the reconstructed light $\delta^{15} \mathrm{~N}$ values (Fig. 3e). These low values have been interpreted as the result of enhanced nitrate supply from the Southern Ocean surpassing the nitrate demand of primary producers in the BUS (Etourneau et al., 2009) and in a much lesser extent, of a possible lighter isotopic signal of the nutrients circulating within the nutricline owing to a more reduced global denitrification (Etourneau et al., 2009; Liu et al., 2008). The nitrate uptake in the Southern Ocean was likely poor due to a weakly iron-stimulated local primary productivity (Martinez-Garcia et al., 2011). In modern conditions, nitrate is not fully consumed in the surface waters of the Southern Ocean because of other limiting factors (silicate and $\mathrm{Fe}$ ) and the nitrate concentration remains year-round high. Compared to today, the overall poor nutrient utilisation by the low primary productivity in this region during the MDM suggests an even more concentrated nitrate pool in this region. When considering that silicate was also poorly consumed in the Southern Ocean as illustrated by the very low siliceous productivity (Cortese et al., 2004), this implies that both nitrate and silicate concentrations in the advected waters circulating through SAMW and AAIW towards the BUS were elevated and their associated isotopic signatures were low.

The observed high (low) degree of fractionation and of silicate (nitrate) utilisation accompanied by the occurrence of a large production of diatom mat-forming species therefore clearly indicates mainly stratified surface water conditions and does not support strong upwelling activity. Numerous 
studies (Berger et al., 2002; Lange et al., 1999; Marlow et al., 2000; Pérez et al., 2001) already suggested that the MDM was characterized by long periods of stratified conditions of surface waters and weak upwelling activity in the BUS due to the presence of $T$. antarctica, a mat-forming diatom species which requires extended periods of stable and stratified conditions for growing and consuming a significant amount of silicate to build their mats. In addition, the appearance of a smaller dominant diatom species (Chaetoceros spores), typical of modern upwelling conditions, only occurred when the MDM declined after 2.4-2.0 Ma (Fig. 2). Very few other diatom species (e.g. Chaetoceros radicans and C. cinctus) that developed under strong upwelling conditions sporadically appeared during the MDM and might have accompanied the excursions to light $\delta^{30} \mathrm{Si}$ as recorded during episodes of BSi MAR low between 3.0 and 2.0 Ma. However, those species remained globally rare and were more abundant in the south than in the north of the BUS (Lange et al., 1999). The distribution of these diatom species along the Namibian coast implies that developed upwelling cells were restricted to the south of the BUS that corroborates the low presence or absence of $T$. antarctica in the southern BUS (Lange et al., 1999). Warm sea surface temperatures (SST) and low north-south SST gradients reported through the Benguela region between 3.0 and $2.4 \mathrm{Ma}$ (see Fig. 3b) also support our assumption that the upwelling activity was globally weak (Etourneau et al., 2009, 2010; Marlow et al., 2000) during the period of increased diatom and opal productivity. This hypothesis is furthermore consistent with pollen data obtained at Site 1082, demonstrating that wetter conditions dominated the first part of the MDM due to weak upwelling activity and enhanced moisture transport to the continent (Dupont et al., 2005; Dupont, 2006). Thus, compelling evidence from different markers strongly supports weak coastal upwelling systems off Namibia as a feature of the Late Pliocene/Early Pleistocene cooling.

According to this line of evidence, we therefore emphasize that nutrient feeding the biological production in the BUS originated from SAWM and AAIW. The diatom species (T. antarctica) dominating the MDM probably mostly migrated through the water column to abundantly feed, in response to global cooling, from shallow thermocline and nutricline waters (Etourneau et al., 2009; Philander and Fedorov, 2003) where the silicate and nitrate-rich SAMW and AAIW circulated. In addition, the growth of diatoms and other phytoplankton species (e.g. coccolithoporids), that were not able to migrate through the water column like diatoms, may have also been sporadically fueled by brief seasonal episodes of mixing supplying nutrients to the surface as well as surface water advection through the Coastal Benguela Current transporting nutrients from the active upwelling cells located south of the BUS.

This weak BUS activity during the MDM was probably closely linked to the system of atmospheric pressure cells that engender strong trade winds and cause the upwelling of deep waters along the Namibian coast. The ocean high pressure cells were likely situated at a more southern position during the MDM owing to warmer atmospheric temperatures and a reduced ice cap over Antarctica, as well as warmer SSTs in the Southern Ocean (Martinez-Garcia et al., 2010; Pollard and Deconto, 2009). This would probably have maintained the South Atlantic high pressure cells far from the African continental low and prevented the formation of strong trade winds along the shore, especially in the northern part of the BUS, thus resulting in a weaker upwelling intensity. The transfer of advected nitrate and silicate-rich waters masses supplying the BUS during the MDM associated with long periods of stratified surface water conditions therefore offered favourable and stable conditions for the growth of mat-forming diatoms, the most significant contributor of biogenic opal production. Silicate was nearly completely consumed by $T$. antarctica for growing and building their extensive mats and progressively became the limiting factor of growth as revealed by their high $\delta^{30} \mathrm{Si}$ signatures. By comparison, the utilisation of nitrate remained much lower owing to its important supply from the Southern Ocean to the BUS, as indicated by the low $\delta^{15} \mathrm{~N}$ signatures.

In contrast, between 2.4 and $2.0 \mathrm{Ma}$, the MDM decline is marked by a pronounced reduction of the biogenic opal production and a progressive shift from Antarctic species (T. antarctica) to upwelling diatom species (Chaetoceros spores and cetae) in concert with the intensification of the upwelling activity (Etourneau et al., 2009; Marlow et al., 2000) and the establishment of a strong meridional atmospheric circulation (Etourneau et al., 2010). In parallel, the polar frontal system in the Southern Ocean developed (Liu et al., 2008), which was accompanied by an increase in Southern Ocean siliceous productivity (Cortese et al., 2004), likely stimulated by increasing iron supply via aeolian dust (MartinezGarcia et al., 2011). This probably restricted the $\mathrm{Si}$ and $\mathrm{N}$ export to low-latitude upwelling regions and the nutrient access to upwelling productivity. Concomitantly, the ${ }^{30} \mathrm{Si}$ values and biogenic opal content in the BUS decreased, whereas the $\delta^{15} \mathrm{~N}$ increased (Fig. 1). Any significant effects of the changing diatom community on $\mathrm{Si}$ isotope fractionation are unlikely because no abrupt variation in $\delta^{30} \mathrm{Si}$ was observed during the shift from Antarctic to upwelling species. We also suppose that the $\delta^{30} \mathrm{Si}$ was essentially only measured on biogenic opal derived from the same diatom species as those producing the organic matter on which bulk $\delta^{15} \mathrm{~N}$ was measured. Hence, taken together these arguments strongly suggest that the decreasing $\delta^{30} \mathrm{Si}$ and increasing $\delta^{15} \mathrm{~N}$ values have been the consequence of a diminished utilisation of silica and a higher utilisation of nitrate, respectively, although the $\delta^{15} \mathrm{~N}$ may be also overprinted by heavier isotope signatures circulating through the nutricline (Etourneau et al., 2009). The development of the upwelling system likely triggered a more continuous supply of both bioavailable Si and $\mathrm{N}$. However, the higher utilisation of nitrate likely drove the latter to become a more limiting factor for phytoplankton 
growth, as illustrated by the higher $\delta^{15} \mathrm{~N}$ values, so that $\mathrm{Si}$ utilisation by local diatoms was reduced and led to lighter $\delta^{30} \mathrm{Si}$ values. In addition, the production of Chaetoceros spores instead of $T$. antarctica probably drove to reduced silicate utilisation and biogenic opal production as the former species generates less biogenic opal owing to their smaller size than the Antarctic species and its lesser competitive capacity against the other micro-organisms.

\section{Implications for Late Pliocene/Early Pleistocene atmospheric $\mathrm{CO}_{2}$}

The shift of the centres of opal deposition away from the polar oceans and low latitudes most likely had fundamental consequences for the carbon cycle and as such may also have had dramatic consequences for global climate. Although further (modelling) studies are required to precisely quantify the impact of the MDM on global climate, our new results suggest a possible scenario linking this event, nutrient distribution and opal productivity changes in the BUS, as well as in other coastal upwelling systems (Fig. 4), to the Late Pliocene/Early Pleistocene global climate shift (Fig. 5),

Here, we propose that during the warm Pliocene (A) vertical mixing probably dominated the surface waters of the polar oceans (Haug et al., 1999; Sigman et al., 2004), whereas conditions of warm surface waters and weak upwelling activity governed the low-latitude eastern boundary current regions (e.g. Etourneau et al., 2009; this study). Siliceous productivity was mainly focused in the Southern Ocean and North Pacific while low phytoplankton productivity, limited by nutrient ( $\mathrm{Si}$ and $\mathrm{N}$ ) supply, developed along the upwelling areas (Cortese et al., 2004). Contrary to the low latitude coastal upwelling systems, the ocean/atmosphere $\mathrm{CO}_{2}$ exchange was probably intense and acted as a source in polar regions, which thus contributed to maintain high atmospheric $p \mathrm{CO}_{2}$ levels (350-400 ppm).

During the Late Pliocene/Early Pleistocene cooling (B), stratification of the Southern Ocean and North Pacific due to the extension of the polar ice caps from 3.0-2.7 Ma (Sigman et al., 2004) likely led to limitation of the ocean-atmosphere exchange in these regions, and therefore progressively reduced the capacity of the polar ocean to release $\mathrm{CO}_{2}$ to the atmosphere, as was the case in the low latitude coastal upwelling regions during the preceding warm Pliocene. This stratification was accompanied by an efficient nutrient leakage towards the low latitudes, stimulating diatom productivity in upwelling areas such as off Benguela, California and Mauritania (Janecek, 2000; Tiedemann, 1991) (Fig. 3), thus replacing the active productivity pumping and removing atmospheric $\mathrm{CO}_{2}$ in the polar regions. This nutrient leakage may have been amplified by a weak Fe fertilisation of the surface waters in the Southern Ocean (Martinez-Garcia et al., 2011), which would have favored an extensive transfer of unused nutrients from the high to the low-latitude oceanic

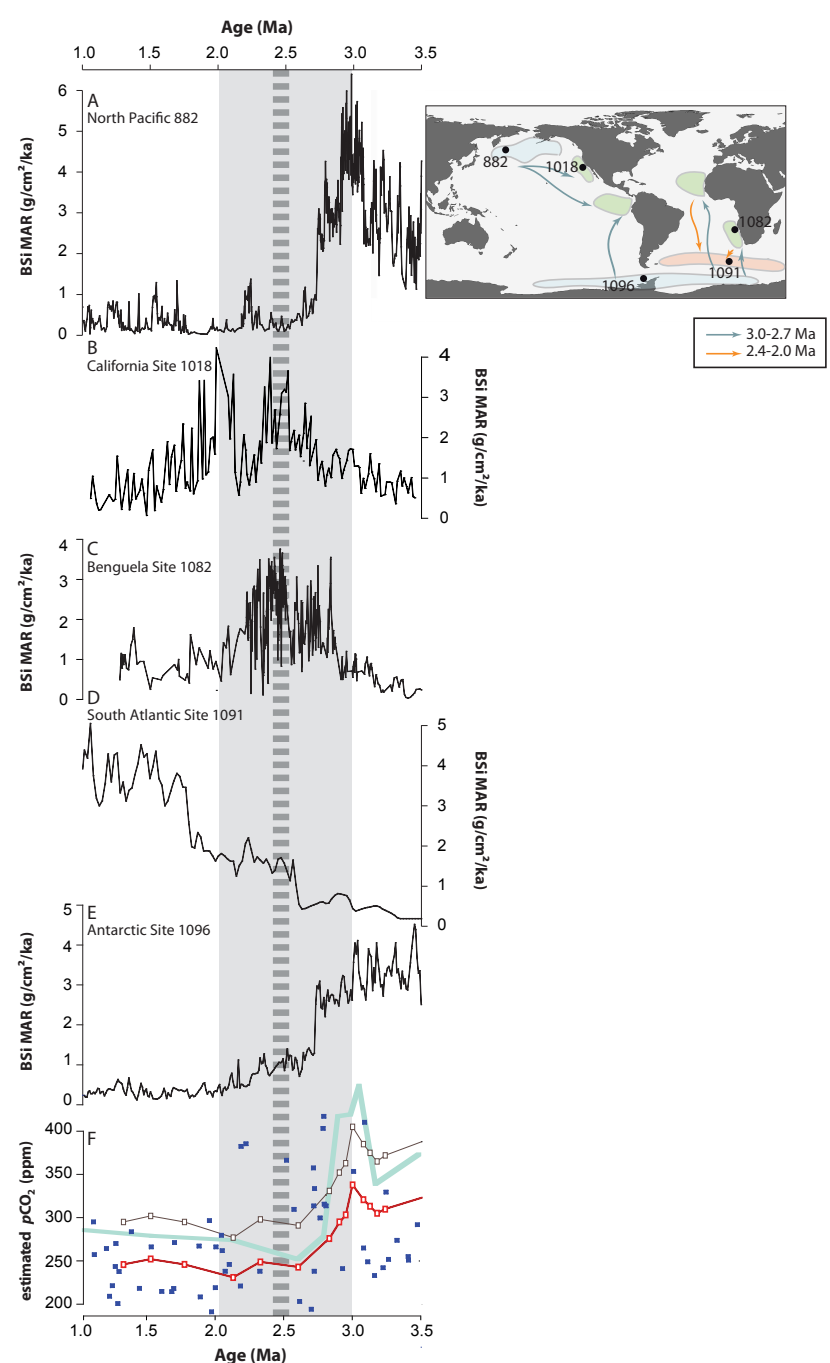

Fig. 4. BSi MAR at Sites (A) 882 (Maslin et al., 1996), (B) 1018 (Janecek, 2000), (C) 1082 (Etourneau et al., 2009), (D) 1091 (Cortese et al., 2004) and (E) 1096 (Hillenbrand and Fütterer, 2001). (F) Atmospheric $p \mathrm{CO}_{2}$ estimate derived from planktic foraminifera (blue line, Seki et al., 2010; blue square, Bartoli et al., 2011; Hönisch et al., 2009) and alkenones (grey and red, Seki et al., 2010) at the Caribbean Site 999. The grey zone corresponds to the period of increasing siliceous productivity and decreasing $p \mathrm{CO}_{2}$ as illustrated by the black arrows. The dashed line indicates the maximum biogenic opal production during the MDM. The associated map shows the respective locations of the different sites and the major opal centres shift, from the Southern Ocean and the North Pacific (blue) to the low-latitudes upwelling regions (green) around 3.0-2.7 Ma, and from the latter to the Atlantic sector of the Southern Ocean (orange) around 2.4-2.0 Ma (modified from Cortese et al., 2004). 

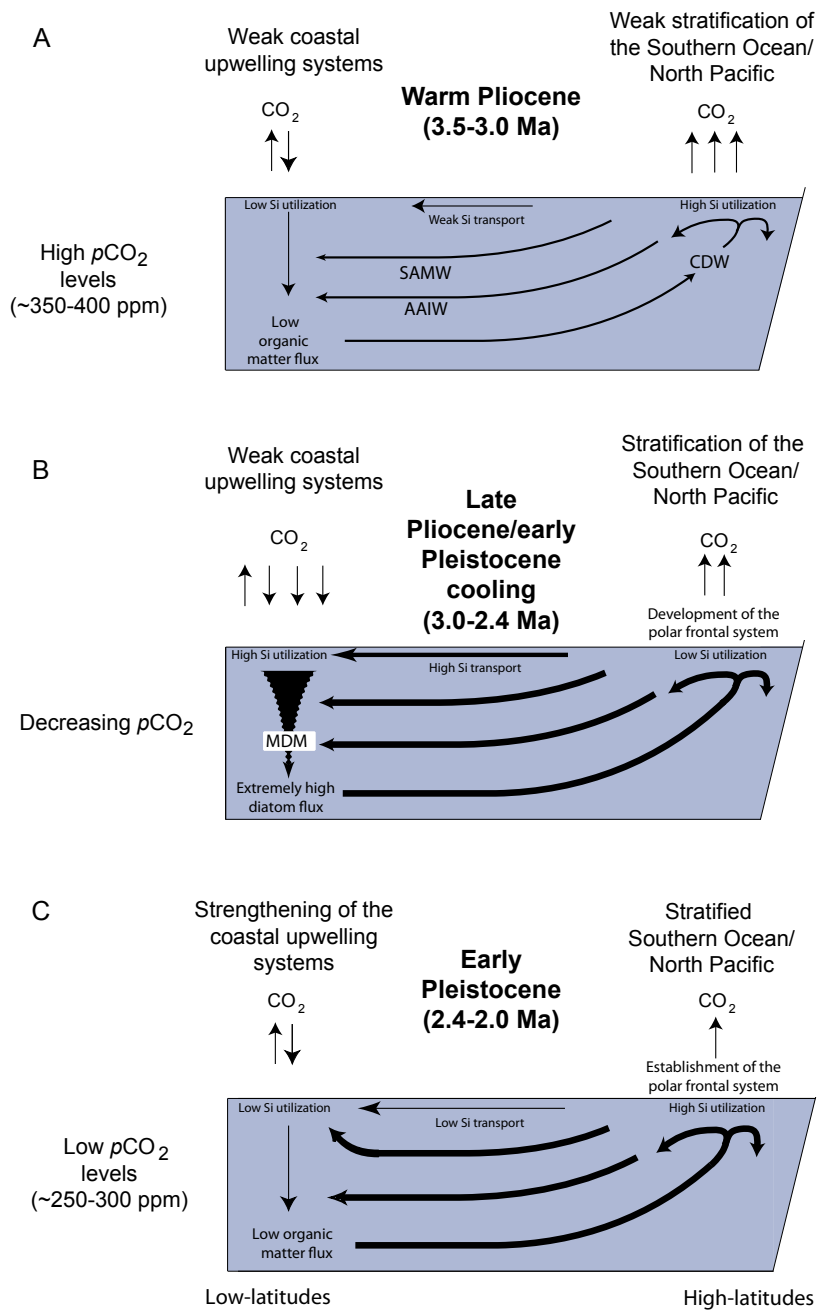

Fig. 5. Proposed scenario representing the Si transport from the Southern Ocean/North Pacific towards upwelling systems and its utilisation by phytoplankton productivity during (A) the warm Pliocene, (B) the Late Pliocene/Early Pleistocene cooling and (C) the early Pleistocene. CDW, Circumpolar Deep Water.

regions and thus promoted high primary productivity rates in these areas. For most of the time, on both decadal scales but probably also during the annual cycle, stratification prevailed within the eastern boundary currents between 2.8 and $2.4 \mathrm{Ma}$ but was interrupted by most likely short seasonal episodes of mixing supplying nutrients, thus fuelling bioproductivity in the low latitude upwelling systems and thereby increasing atmospheric $\mathrm{CO}_{2}$ uptake. The long seasonal period of stratified conditions probably prevented significant upwelling of dissolved $\mathrm{CO}_{2}$-enriched waters to the surface, which diminished the $\mathrm{CO}_{2}$ flux from the ocean to the atmosphere in these regions. Given the extremely high opal production in these regions, we infer that the uptake of $\mathrm{CO}_{2}$ was probably considerably enhanced and higher in flux than release from the deep ocean to the atmosphere via upwelling.
The opposite trends between the opal content in the upwelling systems and global $p \mathrm{CO}_{2}$ recently obtained from several regions (Bartoli et al., 2011; Pagani et al., 2010; Tripati et al., 2010; Seki et al., 2010) probably reflects the impact of the efficiency of the biological pump on atmospheric carbon dioxide levels associated with significant hydrological changes (Fig. 4). Although it remains difficult to precisely estimate the impact of such nutrient and primary productivity reorganization in the Late Pliocene/Early Pleistocene ocean, we suggest that both stratified conditions in the high latitudes and weak upwelling activity in the low latitudes coinciding with high productivity in the coastal upwelling regions probably contributed to a significant reduction of atmospheric $\mathrm{CO}_{2} \sim 3.0-2.7 \mathrm{Ma}$ ago. For comparison, a large silica transfer during the last glacial periods between a stratified Southern Ocean and intensive low-latitude upwelling systems would have accounted for a reduction of the atmospheric $\mathrm{CO}_{2}$ by $60 \mathrm{ppm}$ (Brzezinski et al., 2002). However, it must be noticed that the major difference between the last glacial and the Late Pliocene/Early Pleistocene cooling periods resides in the fact that $\mathrm{Fe}$ dust fertilisation likely did not play a significant role on nutrient utilisation in the Southern Ocean during the MDM, and therefore on nutrient distribution towards the low-latitudes upwelling regions, as $\mathrm{Fe}$ remained poorly transported to the surface waters between 3.0 and 2.0 Ma (Martinez-Garcia et al., 2011) probably as a result of a weak atmospheric circulation and a displacement south of the South Atlantic atmospheric high pressures cells (Etourneau et al., 2010; Martinez-Garcia et al., 2010; this study).

In contrast, when the MDM ended (C), diatom production in the upwelling areas dropped because nutrients were mostly utilised by the opal production developing in the Atlantic sector of the Southern Ocean (Cortese et al., 2004). Less $\mathrm{CO}_{2}$ was thereby sequestered by biological production in the low latitude coastal upwelling areas and the balance between the Southern Ocean and low-latitudes upwelling systems became more equilibrated, thus leading to a slowdown of the $\mathrm{CO}_{2}$ decline (close to 250-300 ppm). In addition, the strengthening of the global upwelling activity from $2.4-2.0 \mathrm{Ma}$ likely increased the exposure of deeper water $\mathrm{CO}_{2}$ to the atmosphere, thus counterbalancing the effects of the phytoplankton production.

Acknowledgements. We greatly thank D. Cardinal for helpful discussions and advice on the interpretation of the silicon isotope data, and L. Collins for the English corrections of the manuscript. We acknowledge the Integrated Ocean Drilling Program for providing the samples of BUS Site 1082. This research was supported by the Deutsche Forschungsgemeinschaft through German projects SCHN 621/12-1 (University of Kiel) and FR1198/3-1 (GEOMAR) and, the French program CNRS-ECLIPSE of P. Martinez (University Bordeaux 1).

Edited by: A. Haywood 


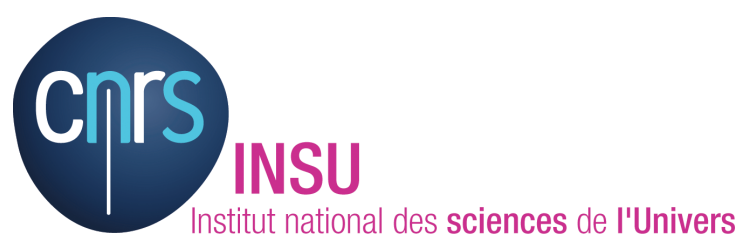

The publication of this article is financed by CNRS-INSU.

\section{References}

Albarède, F., Telouk, P., Blichert-Toft, J., Boyet, M., Agranier, A., and Nelson, B.: Precise and accurate isotopic measurements using multiple-collector ICPMS, Geochim. Cosmochim. Acta, 68, 2725-2744, 2004.

Bartoli, G., Hönisch, B., and Zeebe, R. E.: Atmospheric $\mathrm{CO}_{2}$ decline during the Pliocene intensification of Northern Hemisphere, Paleoceanography, 26, PA4213, doi:10.1029/2010PA002055, 2011.

Berger, W. H., Lange, C. B., and Pérez, M. E.: The early Matuyama Diatom Maximum off SW Africa: a conceptual model, Mar. Geol., 180, 105-116, 2002.

Brzezinski, M. A., Pride, C. J., and Franck, V. M.: A switch from $\mathrm{Si}(\mathrm{OH})_{4}$ to $\mathrm{NO}_{3}^{-}$depletion in the 20 glacial Southern Ocean, Geophys. Res. Lett., 29, 1564, doi:10.1029/2001GL014349, 2002.

Cardinal, D., Savoye, N., Trull, T. W., Dehairs, F., Kopczynska, E. E., Fripiat, F., Turon, J.-L., and André, L.: Silicon isotopes in spring Southern Ocean diatoms: Large zonal changes despite homogeneity among size fractions, Mar. Chem., 106, 46-62, 2007.

Cortese, G., Gersonde, R., Hillenbrand, C.-D., and Kuhn, G.: Opal sedimentation shifts in the World Ocean over the last $15 \mathrm{Myr}$, Earth Planet. Sc. Lett., 224, 509-527, 2004.

De La Rocha, C. L. and Bickle, M. J.: Sensitivity of silicon isotopes to whole-ocean changes in the silica cycle, Mar. Geol., 217, 267282, 2005

De La Rocha, C. L., Brzezinski, M. A., and DeNiro, M. J.: Fractionation of silicon isotopes by marine diatoms during biogenic silica formation, Geochim. Cosmochim. Acta, 61, 5051-5056, 1997.

De La Rocha, C. L., Brzezinski, M. A., DeNiro, M. J., and Shemesh, A.: Silicon-isotope composition of diatoms as an indicator of past oceanic change, Nature, 395, 680-683, 1998.

De La Rocha, C. L., Brzezinski, M. A., and DeNiro, M. J.: A first look at the distribution of the stable isotopes of silicon in natural waters, Geochim. Cosmochim. Acta, 64, 2467-2477, 2000.

De Souza, G. F., Reynolds, B. C., Rickli, J., Frank, M., Saito, M. A., Gerringa, L. J. A., and Bourdon, B.: Southern Ocean control of silicon stable isotope distribution in the deep Atlantic Ocean, Global Biogeochem. Cy., 26, GB2035, doi:10.1029/2011GB004141, 2012.

Dekens, P. S., Ravelo, A. C., and McCarthy, M. D.: A warm upwelling regions in the Pliocene warm period, Paleoceanography, 22, PA3211, doi:10.1029/2006PA001394, 2007.

Demarest, M. S., Brzezinski, M. A., and Beucher, C. P.: Fractionation of silicon isotopes during silica dissolution, Geochim. Cosmochim. Acta, 73, 5572-5583, 2009.
Dupont, L., Donner, B., Vidal, L., Pérez, E. M., and Wefer, G.: Linking desert evolution and coastal upwelling: Pliocene climate change in Namibia, Geology, 33, 461-464, 2005.

Dupont, L. M.: Late Pliocene vegetation and climate in Namibia (southern Africa) derived from palynology of ODP Site 1082, Geochem. Geophy. Geosy., 7, Q05007, doi:10.1029/2005GC001208, 2006.

Etourneau, J., Martinez, P., Blanz, T., and Schneider, R.: PliocenePleistocene variability of upwelling activity, productivity, and nutrient cycling in the Benguela region, Geology, 37, 871-874, 2009.

Etourneau, J., Schneider, R., Blanz, T., and Martinez, P.: Intensification of the Walker and Hadley circulations during the PliocenePleistocene climate transition, Earth Planet. Sc. Lett., 297, 103110, 2010.

Fripiat, F., Cavagna, A.-J., Savoye, N. Dehairs, F., André, L., and Cardinal, D.: Isotopic constraints on the Si-biogeochemical cycle oft he Antarctic Zone in the Kerguelen area (KEOPS), Mar. Chem., 123, 11-22, 2011.

Georg, R. B., Reynolds, B. C., Frank, M., and Halliday, A .N.: New sample preparation techniques for the determination of $\mathrm{Si}$ isotopic compositions using MC-ICPMS, Chem. Geol., 235, 95104, 2006.

Gersonde, R., Hodell, D. A., Blum, P., and Shipboard Scientific Party: Proc. Ocean Drill. Init. Rep. 177, Ocean Drill. Progr., College Station, Texas, 1999.

Hansen, H. P. and Koroleff, F.: Determination of nutrients, in: Methods of Seawater Analysis, 3rd Edn., edited by: Grasshoff, K., Kremling, K., and Erhardt, M., Wiley VHC, 159-228, 1999.

Haug, G. H., Sigman, D. M., Tiedemann, R., Pedersen, T. F., and Sarnthein, M.: Onset of permanent stratification in the subarctic Pacific Ocean, Nature, 401, 779-782, 1999.

Herbert, T. D. and Schuffert, J. D.: Alkenone unsaturation estimates of late Piocene through late Pliocene sea-surface temperature at Site 958, Proc. Ocean Drill. Progr. Sci. Res. 159, Ocean Drill. Progr., College Station, Texas, 1998.

Hillenbrand, C. D. and Cortese, G.: Polar stratification: A critical view from the Southern Ocean, Palaeogeogr. Palaeocl., 242, 240-252, 2006.

Hillenbrand, C.-D. and Fütterer, D. K.: Neogene to Quaternary deposition of opal on the continental rise west of the Antarctic Peninsula, ODP Leg 178, Sites 1095, 1096, and 1101, Proc. Ocean Drill. Prog. Sci. Res. 178, Ocean Drill. Progr., College Station, Texas, 2001.

Hönisch, B., Gary Hemming, N., Archer, D., Siddall, M., and McManus, J.F.: Atmospheric carbon dioxide concentration across the Mid-Pleistocene Transition, Science, 324, 1551-1554, 2009.

Janecek, T. R.: Data report: Late neogene biogenic opal data Leg 167 sites on the California margin, Proc. Ocean Drill. Progr Sci. Res. 167, Ocean Drill. Progr., College Station, Texas, 2000.

Koning, E., van Iperen, J. M., van Raaphorst, W., Helder, W., Brummer, G.-J. A., and van Weering, T. C. E.: Selective preservation of upwelling-indicating diatoms in sediments off Somalia, NW Indian Ocean, Deep-Sea Res. Pt. I, 48, 2473-2495, 2001.

Lange, C. B., Berger, W. H., Lin, H.-L., Wefer, G., and Shipboard Scientific Party leg 175: The early Matuyama Diatom Maximum off SW Africa, Benguela current system (ODP leg 175), Mar. Geol., 161, 93-114, 1999. 
Lisiecki, L. E. and Raymo, M. E.: A Pliocene-Pleistocene stack of 57 globally distributed benthic $\delta^{18} \mathrm{O}$ records, Paleoceanography, 20, PA1003, doi:10.1029/2004PA001071, 2005.

Liu, Z., Altabet, M. A., and Herbert, T. D.: Plio-Pleistocene denitrification in the eastern tropical North Pacific: Intensification at 2.1 Ma, Geochem. Geophy. Geosy., 9, Q11006, doi:10.1029/2008GC002044, 2008.

Lunt, D. J., Foster, G. L., Haywood, A. M., and Stone, E. J.: Late Pliocene Greenland glaciation controlled by a decline in atmospheric $\mathrm{CO}_{2}$ levels, Nature, 454, 1104-1106, 2008.

Marlow, J. R., Lange, C. L., Wefer, G., and Rosell-Melé, A.: Upwelling intensification as part of the Pliocene-Pleistocene climate transition, Science, 290, 2288-2291, 2000.

Martinez-Garcia, A., Rosell-Melé, A., McClymont, E., Gersonde, R., and Haug, G.: Subpolar link to the emergence of the modern equatorial Pacific cold tongue, Science, 328, 1550-1553, 2010.

Martinez-Garcia, A., Rosell-Melé, A., Jaccard, S. L., Geibert, W., Sigman, D., and Haug, G.: Southern Ocean dust-climate coupling over the past four million years, Nature, 476, 312-316, 2011.

Maslin, M. A., Haug, G. H., Sarnthein, M., and Tiedemann, R.: The progressive intensification of northern hemisphere glaciation as seen from the North Pacific, Geolog. Rundschau, 85, 452-465, 1996.

Morley, D. W., Leng, M. J., Mackay, A. W., Sloane, H. J., Rioual, P., and Battarbee, R. W.: Cleaning of lake sediment samples for diatom oxygen isotope analysis, J. Paleolimnol., 31, 391-401, 2004.

Pagani, M., Liu, Z., LaRiviere, J., and Ravelo, A. C.: High Earthsystem climate sensitivity determined from Pliocene carbone dioxide concentrations, Nat. Geosci., 3, 27-30, 2010.

Pérez, M. E., Lin, H.-L., Lang, C. B., and Schneider, R.: PliocenePleistocene opal records off southwest Africa, Sites 1082 and 1084: A comparison of analytical techniques, Proc. Ocean Drill. Progr. Sci. Res. 175, Ocean Drilling Program, College Station, Texas, 2001.

Philander, S. G. and Fedorov, A. V.: Role of tropics in changing the response to Milankovitch forcing some three million years ago, Paleoceanography, 18, 1045, doi:10.1029/2002PA000837, 2003.

Pichevin, L., Martinez, P., Bertrand, P., Giraudeau, J., and Schneider, R.: Nitrogen cycling on the Namibian shelf and slope over the last two climatic cycles: Local and global forcings, Paleoceanography, 20, PA2006, doi:10.1029/2004PA001001, 2005.

Pollard, D. and DeConto, R. M.: Modelling West Antarctic ice sheet growth and collapse throughg the past five million years, Nature, 458, 329-333, 2009.
Ragueneau, O., Tréguer, P., Leynaert, A., Anderson, R. F., Brzezinski, M. A., DeMaster, D. J., Dugdale, R. C., Dymond, J., Fischer, G., François, R., Heinze, C., Maier-Reimer, E., Martin-Jézéquel, V., Neslon, D. M., and Quéguiner, B.: A review of the Si cycle in the modern ocean: recent progress and missing gaps in the application of biogenic opal as paleoproductivity proxy, Global Planet. Change, 26, 317-365, 2000.

Reynolds, B. C., Aggarwal, J., André, L., Baxter, D., Beucher, C., Brzezinski, M.A., Engström, E., Georg, R.B., Land, M., Leng, M.J., Opfergelt, S., Rodushkin, I., Sloane, H.J., van der Boorn, H.J.M., Vroon, P.Z., and Cardinal, D.: An inter-laboratory comparison of Si isotope reference materials, J. Analyt. Atomic Spectrom. 22, 561-568, 2007.

Reynolds, B. C., Frank, M., and Halliday, A. N.: Silicon isotope fractionation during nutrient utilization in the North Pacific, Earth Planet. Sc. Lett., 244, 431-443, 2006.

Reynolds, B. C., Frank, M., and Halliday, A. N.: Evidence for a major change in silicon cycling in the North Pacific at $2.73 \mathrm{Ma}, \mathrm{Pa}-$ leoceanography, 23, PA4219, doi:10.1029/2007PA001563, 2008.

Robinson, R. S. and Meyers, P.: Biogeochemical changes within the Benguela Current upwelling system during the Matuyama Diatom Maximum: Nitrogen isotope evidence from Ocean Drilling Program Sites 1082 and 1084, Paleoceanography, 17, 1064, doi:10.1029/2001PA000659, 2002.

Seki, O., Foster, G. L., Schmidt, D. N., McKensen, A., Kawamura, K., and Pancost, R.: Alkenone and boron-based Pliocene $p \mathrm{CO}_{2}$ records, Earth Planet. Sc. Lett., 292, 201-211, 2010.

Shannon, L. V.: The Benguela ecosystem, Part I. Evolution of the Benguela physical features and processes, in: Oceanography and marine biology, An Annual review, 23, Aberdeen, edited by: Barnes, M., Aberdeen University Press, 105-182, 1985.

Sigman, D. M., Jaccard, S. A., and Haug, G. H.: Polar ocean stratification in a cold climate, Nature, 428, 59-63, 2004.

Tiedemann, T.: Acht Millionen Jahre Klimageschichte von Nordwest Afrika und Paläo-Ozeanographie des angrenzenden Atlanktis: hochauflösende Zeitreihen von ODP-Sites 658-661, Berichte-Reports, Geol.-Paläontologisches Institut, Univ. Kiel, 46, 190 pp., 1991.

Tripati, A., Roberts, C. R., and Eagle, R. A.: Coupling of $\mathrm{CO}_{2}$ and ice sheet stability over major climate transitions of the last 20 million years, Science, 326, 1394-1397, 2010.

Varela, D. E., Pride, C. J., and Brzezinski, M. A.: Biological fractionation of silicon isotopes in Southern Ocean surface waters, Global Biogeochim. Cy., 18, GB1047, doi:10.1029/2003GB002140, 2004.

Wefer, G., Berger, W. H., Richter, C., and Shipboard Scientific Party: Proc. Ocean Drill. Init. Rep. 175, Ocean Drilling Program, College Station, Texas, 1998. 